\title{
Kegiatan Menyanyi dalam Pembelajaran Anak Usia Dini
}

\author{
Nur Hayati, Arumi Savitri Fatimaningrum, Rina Wulandari, Muthmainnah \\ Program Studi PG PAUD, Fakultas Ilmu Pendidikan, Universitas Negeri Yogyakarta \\ Jalan Colombo No. 1 Yogyakarta, Indonesia \\ E-mail: nurhayati@uny.ac.id
}

\begin{tabular}{|c|c|}
\hline ARTICLE INFO & ABSTRACT \\
\hline $\begin{array}{l}\text { Article history: } \\
\text { Received: } 9-12-2019 \\
\text { Revised: } 16-12-2019 \\
\text { Accepted: } 23-12-2019\end{array}$ & $\begin{array}{l}\text { Tujuan penelitian ini adalah untuk mengetahui persepsi guru terkait kegiatan } \\
\text { menyanyi dalam pembelajaran anak. Guru masih beranggapan bahwa hafal lirik, } \\
\text { menyanyi sesuai nada, berani menyanyi di depan sebagai indikator bahwa } \\
\text { perkembangan aspek seni pada anak telah optimal. Metode penelitian adalah } \\
\text { survey terhadap pendidik PAUD di Kecamatan Banguntapan Bantul Yogyakarta. }\end{array}$ \\
\hline \multirow[t]{2}{*}{$\begin{array}{l}\text { Keywords: } \\
\text { Teachers' perception, } \\
\text { learning process, singing }\end{array}$} & $\begin{array}{l}\text { Subyek penelitian sebanyak } 29 \text { guru, teknik analisis data menggunakan deskriptif } \\
\text { kuantitatif Hasil penelitian terbagi menjadi dua bagian. Bagian pertama untuk } \\
\text { mengetahui apa yang dirasakan guru mengenai kegiatan menyanyi, kemudian } \\
\text { guru-guru di TK apakah menyukai kegiatan menyanyi. Kegiatan menyanyi } \\
\text { apakah dapat mempengaruhi perkembangan anak serta pesan moral dari syair } \\
\text { lagu dapat dipahami anak sehingga kegiatan dapat mengubah perilaku anak. } \\
\text { Bagian kedua penelitian ini untuk mengetahui apa yang dilakukan guru dalam } \\
\text { kegiatan menyanyi. Bagaimana guru mempersiapkan lagu yang akan } \\
\text { disampaikan pada anak termasuk alat music dan cara guru mendapatkan ide } \\
\text { membuat lagu baru. Informasi yang diperoleh dari subjek penelitian } \\
\text { menggambarkan bahwa kegiatan menyanyi yang disampaikan guru pada anak } \\
\text { usia dini ada dipersiapkan dan ada yang spontan. Sehingga dapat dipahami bahwa } \\
\text { kegiatan menyanyi ada yang berpengaruh terhadap kegiatan pembelajaran namun } \\
\text { ada pula yang tidak bermakna. }\end{array}$ \\
\hline & $\begin{array}{l}\text { The aim of the research is to determine teachers' perception regarding singing } \\
\text { activities in children's learning process. Teachers still consider that being able to } \\
\text { memorize lyrics, sing harmoniously, and being brave to sing before the others as } \\
\text { the indicators of the optimal artistic development. A survey was performed to the } \\
\text { teachers of preschool in Banguntapan district Yogyakarta as the research } \\
\text { method. Subjects of the research were } 29 \text { teachers. The data were then analyzed } \\
\text { using descriptive quantitative approach. The results were divided into two parts. } \\
\text { The first is part is to determine how the teachers feel about singing activities and } \\
\text { the third is to determine what the teachers do during the singing activities. }\end{array}$ \\
\hline
\end{tabular}

\section{PENDAHULUAN}

Kegiatan seni merupakan salah satu kegiatan menarik yang diterapkan di Pendidikan Anak Usia Dini. Seni memiliki penafsiran yang berbeda dengan motorik, meskipun perkembangan motorik dan seni memiliki keterkaitan. Seni lebih diarahkan pada kreativitas dan pengalaman estetika, bukan kerapian karya, kemiripan gambar, keluwesan gerakan atau kemerduan suara. Terkait sub komponen penilaian maka penilaian kemampuan menyanyi anak sering didasarkan pada tepat atau tidaknya nada yang dinyanyikan, ataupun mirip / tidaknya gerak kupu-kupu yang dilakukan anak dengan gerak kupukupu. Hasil wawancara dengan Dwi Siswoyo pada tanggal 14 Januari 2018 menunjukkan bahwa tujuan seni untuk anak yaitu kebebasan mengungkapkan gagasan mereka. Bahkan, kertas kosong bergambar lingkaran, dapat memiliki arti yang sungguh di luar perkiraan kita. Pengembangan seni di Pendidikan Anak Usia Dini dapat dilakukan dengan kegiatan menyanyi. Bagi anak, menyanyi merupakan salah satu metode yang menarik dan menyenangkan. Bernyanyi merupakan kegiatan melantunkan suara dan biasanya disertai dengan tepuk, gerakan, atau iringan musik. Melalui kegiatan menyanyi, anak dapat mengenal ritme, memahami suatu konsep sesuai isi lirik, mengekspresikan diri, dan masih banyak lagi. 
Hasil wawancara dan observasi terhadap guru TK di Kecamatan Berbah, Sleman Yogyakarta pada tanggal 2-10 Oktober 2017 diperoleh data antara lain: 1) kegiatan menyanyi dilakukan pada kegiatan awal, inti, maupun penutup dimana aspek perkembangan seni terkadang tidak dilakukan dalam kegiatan tersebut, 2) indikator penilaian perkembangan seni musik adalah ketepatan nada dan hafal syair lagu. Apakah ini yang disebut kebebasan mengungkapkan gagasan? 3) bernyanyi sambil bergerak merupakan indikator aktivitas musikal, namun sering tidak dinilai, 4) menyanyi sesuai syair lagu dan ataupun iringan masih dianggap sebagai salahsatu aktivitas stimulasi perkembangan seni musik. Bukankah hal tersebut kental dengan aspek kognitif? Bagaimana dengan stimulasi kebebasan ungkapan dari diri anak? 5) bernyanyi sering dilakukan sebatas pada upaya ice breaking. Namun jika dilihat dari pernyataan sebelumnya, melalui kegiatan menyanyi, dapat dilakukan penilaian terkait ungkapan apa yang anak lakukan dari suara yang mereka hasilkan yang bahkan kadang berbeda dengan lagu yang seharusnya.

Hasil penelitian Martha Christianti, Nur Hayati dan Arumi Savitri Fatimaningrum (2017) menunjukkan bahwa anak usia dini membutuhkan penguatan yang terus menerus dari orang dewasa dalam proses menuangkan pengalamannya khususnya pengenalan literasi. Dalam proses pembelajaran di Taman Kanak-kanak, guru berperan sebagai model untuk mengenalkan berbagai pengetahuan kepada anak. Dengan demikian peran guru, orang tua maupun orang dewasa di sekitar anak sangat berarti bagi perkembangan anak. Berdasarkan fakta di lapangan, maka penelitian ini bertujuan untuk mengetahui bagaimana persepsi guru terhadap kegiatan menyanyi dalam pembelajaran anak usia dini. Dengan terungkapnya data persepsi guru, peneliti dapat mengurai permasalahan pembelajaran seni khususnya seni musik yang terjadi selama ini. Dengan demikian kegiatan menyanyi diharapkan dapat dilakukan sesuai dengan tingkat pencapaian perkembangan anak dan mengoptimalkan perkembangan anak usia dini.

\section{Persepsi}

Slameto (2010: 102) menjelaskan pengertian persepsi sebagai proses yang berkaitan dengan masuknya pesan atau informasi ke dalam otak manusia, melalui persepsi manusia terus menerus mengadakan hubungan dengan lingkungannya. Hubungan ini dilakukan lewat indranya, yaitu indra pengelihat, pendengar, peraba, pengecap, dan pencium. Meskipun persepsi banyak dikaitkan dengan penerimaan hasil kerja dari pancaindra, Solso et. al. (2007: 75) menegaskan bahwa pendeteksian dini terhadap stimulasi adalah bagian dari sensasi, sementara persepsi mengacu pada interpretasi terhadap hal-hal yang diterima oleh pancaindra.

Menurut Asrori (2009: 214) pengertian persepsi adalah proses individu dalam menginterpretasikan, mengorganisasikan dan memberi makna terhadap stimulus yang berasal dari lingkungan di mana individu itu berada yang merupakan hasil dari proses belajar dan pengalaman. Dalam pengertian persepsi tersebut terdapat dua unsur penting yakni interpretasi dan pengorganisasian. Interpretasi merupakan upaya pemahaman dari individu terhadap informasi yang diperolehnya. Sedangkan perorganisasian adalah proses mengelola informasi tertentu agar memiliki makna. Dari uraian di atas dapat disimpulkan bahwa persepsi merupakan proses individu dalam menginterpretasikan, mengorganisasikan dan memberi makna terhadap stimulus. Stimulus merupakan hasil dari proses belajar dan pengalaman yang berasal dari lingkungan di mana individu itu berada.

Menurut Irwanto (2002: 71), setelah individu melakukan interaksi dengan objek-objek yang dipersepsikan maka hasil persepsi dapat dibagi menjadi dua, yaitu:

a. Persepsi positif. Persepsi yang menggambarkan sehala pengetahuan (tahu tidaknya atau kenal tidaknya) dan tanggapan yang diteruskan adalah upaya pemanfaatannya.

b. Persepsi negatif. Persepsi yang menggambarkan sehala pengetahuan (tahu tidaknya atau kenal tidaknya) dan tanggapan yang tidak selaras dengan objek yang dipersepsi.

Dapat dikatakan bahwa persepsi baik yang positif maupun negatif akan selalu mempengaruhi seseorang dalam melakukan suatu tindakan.

\section{Kegiatan Menyanyi}

Menyanyi merupakan salah satu kegiatan pengembangan seni musik dalam pembelajaran ana usia dini (Wulandari, 2011). STPPA usia dini aspek seni dalam Permendikbud no 137 tahun 2014 dapat dimaknai bahwa melalui kegiatan menyanyi, anak dapat mengeksplorasi dan mengekspresika diri, berimaginasi dengan gerakan, musik, drama, dan beragam bidang seni lainnya (seni lukis, seni 
rupa, kerajinan), serta mampu mengapresiasi karya seni. Kedua pendapat tersebut dapat dijadikan acuan bahwa kegiatan menyanyi tidak hanya sekedar kegiatan yang meramaikan suasana, namun merupakan aktivitas yang penuh dengan tujuan dan makna.Siapapun yang melakukan kegiatan menyanyi secara tidak langsung mengeksplorasi apa yang telah didengar dan diketahui.

Tujuan pendidikan anak usia dini yang tercantum dalam kurikulum 2013 tertulis salah satu cara menilai keterampilan peserta didik dengan menunjukkan yang diketahui, dirasakan, dibutuhkan, dan dipikirkan melalui bahasa, musik, gerakan, dan karya secara produktif dan kreatif, serta mencerminkan perilaku anak berakhlak mulia. Kegiatan menyanyi yang dapat dimaknai salah satu aktivitas seni musik dapat dijadikan sebagai tolak ukur mengetahui keterampilan individu setelah memperoleh informasi sebelumnya.

\section{Pembelajaran Anak Usia Dini}

Belajar dapat diartikan sebagai suatu proses perubahan tingkah laku pada diri seseorang, sebagai indikator bahwa seseorang telah melakukan aktivitas yang tercermin dari perubahan perilakunya (Nur Hayati, dkk: 2015). Aktivitas yang dilakukan anak setiap hari merupakan pengalaman berharga yang dapat menstimulasi berbagai aspek perkembangan anak usia dini. Karakteristik anak usia 0-6 tahun yang masih egosentris menjadi landasan bagi pembelajaran anak usia dini yang lebih banyak menggunakan teori belajar behavioristik dan konstruktivistik.

Piaget maupun Vygotsky berpendapat bahwa belajar merupakan sebuah proses yang dilakukan anak secara aktif untuk membangun ide-ide atau konsep baru yang didasarkan pada pengetahuan atau pengalamannya baik yang sudah lama ataupun yang baru (Nur Hayati dkk, 2015). Dengan demikian anak harus diberi kebebasan dan kesempatan untuk mengeksplorasi diri dan lingkungannya guna memperoleh pengetahuan sendiri. Keberhasilan pembelajaran akan tercapai sesuai dengan standar tingkat pencapaian perkembangan anak yaitu dari aspek Nilai Agama dan Moral (NAM), Fisik Motorik, Kognitif, Bahasa, Sosial Emosional serta Seni.

\section{METODE}

Jenis penelitian ini adalah survey. Metode penelitian menggunakan deskriptif kualitatif. Instrumen penelitian menggunakan angket terbuka. Subjek penelitian adalah guru PAUD di Kecamatan Banguntapan, Bantul, Yogyakarta. Waktu penelitian dilaksanakan bulan April 2018. Subjek penelitian berjumlah 29 Guru PAUD. Prosedur penelitian meliputi pengkajian teori tentang persepsi guru, merumuskan definisi konseptual dan operasional, menyusun indikator persepsi guru, menyusun instrumen persepsi guru tentang kegiatan menyanyi dalam bentuk angket terbuka, pengumpulan data, reduksi dan tabulasi data, analisis data deskriptif kualitatif, dan penarikan kesimpulan. Teknik analisis data melalui penjabaran data, pengelompokkan data, memaknai data dari sudut pandang teori persepsi terhadap kegiatan menyanyi dan penyimpulan data hasil penelitian.

\section{HASIL DAN PEMBAHASAN}

\section{Hasil}

Hasil penelitian ini terdiri dari dua bagian, yaitu bagian pertama tentang apa yang dirasakan guru terhadap kegiatan menyanyi dan bagian kedua apa yang dilakukan guru dalam kegiatan menyanyi.

\section{Perasaan yang Dimiliki Guru Tentang Kegiatan Menyanyi Apakah guru meminati kegiatan menyanyi?}

Data di lapangan menunjukkan bahwa guru meminati kegiatan menyanyi karena menyanyi merupakan kegiatan yang sangat menyenangkan, membuat anak menjadi lebih bersemangat, dan memudahkan komunikasi antara guru dengan anak. Guru merasa senang melakukan kegiatan menyanyi karena anak menjadi lebih bersemangat. Adapun gambaran jumlah guru yang meminati kegiatan menyanyi dapat dilihat pada gambar dibawah ini: 
Nur Hayati, Arumi Savitri Fatimaningrum, Rina Wulandari, Muthmainnah

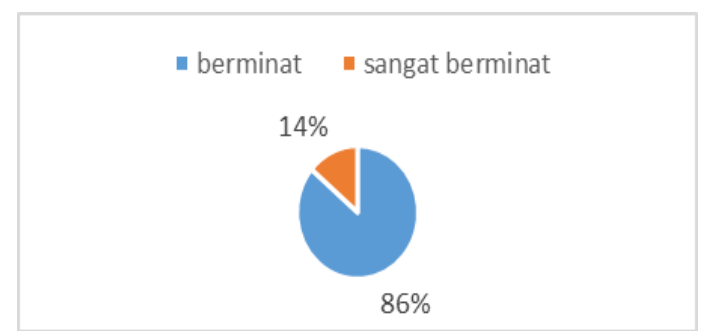

Gambar 1. Minat guru dalam kegiatan menyanyi

Berdasarkan gambar diatas dapat diketahui bahwa $86 \%$ guru meminati kegiatan menyanyi dan $14 \%$ sangat meminati kegiatan menyanyi.

\section{Apakah guru senang dengan kegiatan menyanyi?}

Hasil penelitian menunjukkan bahwa sebagian besar (83\%) guru senang dengan kegiatan menyanyi dan sebagian kecil (17\%) guru menyatakan sangat senang dengan kegiatan menyanyi. Data lengkapnya dapat dilihat pada gambar 2 dibawah ini:

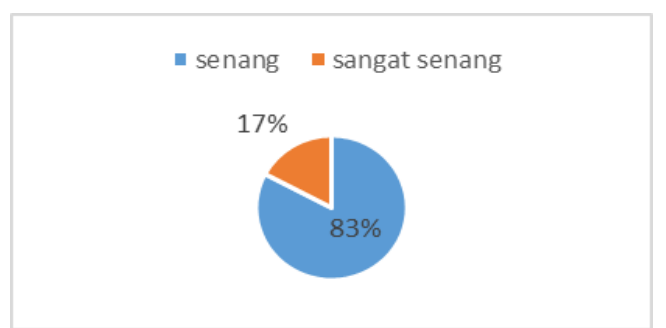

Gambar 2. Perasaan guru saat kegiatan menyanyi

\section{Apakah kegiatan menyanyi mempengaruhi aspek perkembangan anak yang lain?}

Data dilapangan menunjukkan bahwa sebagian besar guru menyatakan menyanyi dapat mempengaruhi aspek perkembangan selain seni. Aspek perkembangan yang terpengaruh yaitu aspek sosio emosional, kognitif, bahasa, nilai agama dan moral. Hal tersebut dapat terlihat ketika anak dapat mengungkapkan ekspresinya dan percaya diri. Anak mampu mengingat lirik lagu, kosa kata anak bertambah serta nasihat yang tersirat dari lagu dapat merubah perilaku anak. Gambaran detailnya dapat diamati dari gambar 3.

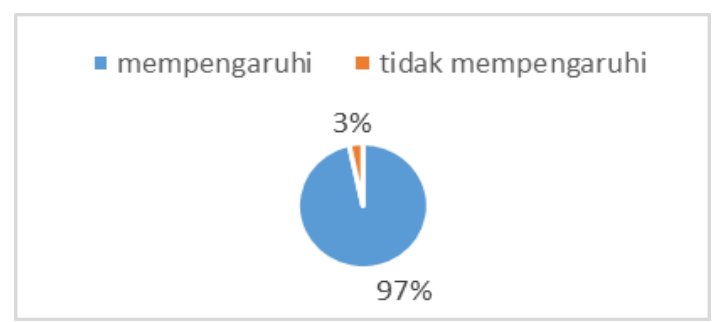

Gambar 3. Pengaruh kegiatan menyanyi terhadap aspek perkembangan lain

Gambar 3 menunjukkan bahwa sebagan besar (97\%) guru mempunyai persepsi bahwa kegiatan menyanyi dapat mempengaruhi aspek perkembangan anak yang lain. Dan 3\% guru menyatakan kegiatan menyanyi tidak mempengaruhi aspek perkembangan anak yang lain.

\section{Apakah anak dapat memahami pesan moral dari syair lagu?}

Hasil survey menunjukkan bahwa sebagian besar guru (93\%) mempunyai persepsi bahwa anak akan dapat memahami pesan moral dari syair lagu. $7 \%$ guru mempunyai persepsi bahwa anak tidak atau kurang memahami pesan moral syair lagu. Adapun gambar pemahaman pesan moral dapat dilihat pada gambar 4. 
Nur Hayati, Arumi Savitri Fatimaningrum, Rina Wulandari, Muthmainnah

- bisa memahami

- tidak/kurang bisa memahami

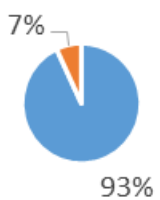

Gambar 4. Pemahaman pesan moral dari syair lagu

\section{Apakah kegiatan menyanyi dapat mengubah perilaku anak.}

Guru mempunyai persepsi bahwa kegiatan menyanyi dapat mengubah perilaku anak. 4 Guru mempunyai persepsi kegiatan menyanyi dapat mengubah suasana hati. Selain itu kegiatan menyanyi juga dapat melembutkan perasaan anak, meningkatkan komunikasi, membuat percaya diri dan mengajarkan etika. Gambaran lebih detailnya dapat dilihat pada gambar 5.

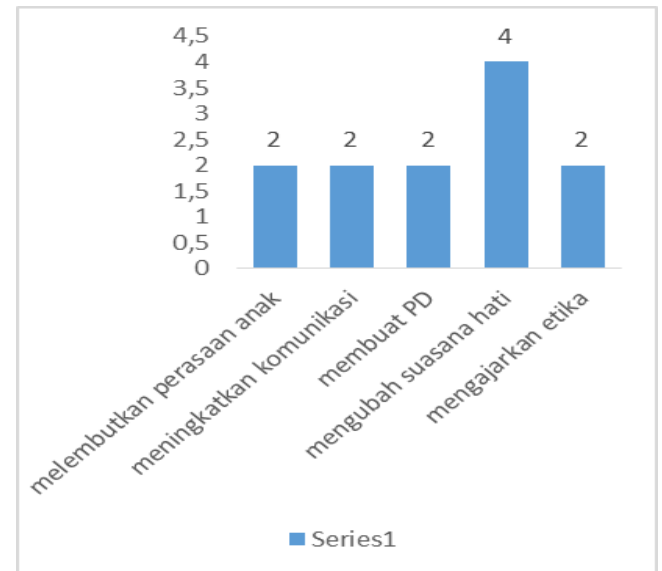

Gambar 5. Persepsi guru bahwa kegiatan menyanyi dapat merubah perilaku anak

\section{Apa yang dilakukan Guru dalam Kegiatan Menyanyi}

Apakah guru mempersiapkan lagu yang sesuai dengan tema pembelajaran?

Hasil survey menunjukkan 90\% guru mempunyai persepsi perlu menyiapkan lagu sesuai dengan tema pembelajaran, $7 \%$ guru menyatakan sebaiknya menyiapkan lagu sesuai tema dan $3 \%$ guru menyatakan kadang-kadang menyiapkan lagu sesuai dengan tema pembelajaran

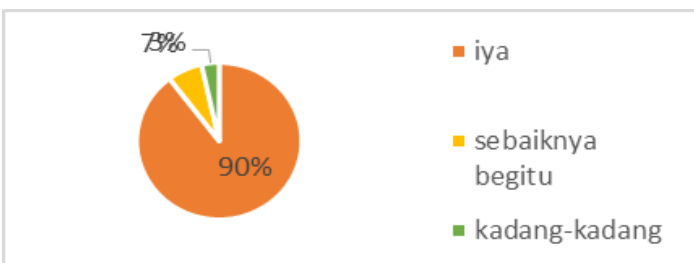

Gambar 6. Persepsi guru menyiapkan lagu sesuai tema pembelajaran

\section{Apakah Guru mencantumkan kegiatan menyanyi dalam RPPH?}

Data d ilapangan menunjukkan sebagian besar guru mempunyai persepsi perlu mencantumkan kegiatan menyanyi dalam RPPH dengan alasan agar dapat terprogram dan dapat dievaluasi. 
Nur Hayati, Arumi Savitri Fatimaningrum, Rina Wulandari, Muthmainnah

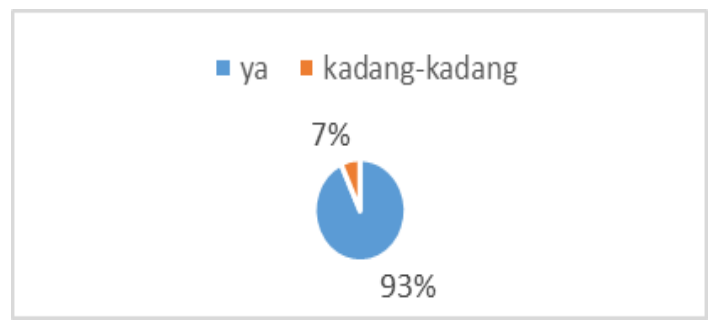

Gambar 7. Persepsi guru mencantumkan kegiatan menyanyi dalam RPPH

Gambar 7 menunjukkan 93\% guru mencantumkan kegiatan menyanyi dalam RPPH dan 7\% guru kadang-kadang mencantumkan kegiatan menyanyi dalam RPPH.

\section{Apakah guru menggunakan alat musik untuk mengiringi anak menyanyi?}

Penelitian menunjukkan bahwa $62 \%$ guru kadang-kadang menggunakan alat musik untuk mengiringi lagu, $24 \%$ guru tidak menggunakan alat musik. 14\% Guru menggunakan alat musik untuk mengiringi lagu karena sekolah memiliki fasilitas alat musik.

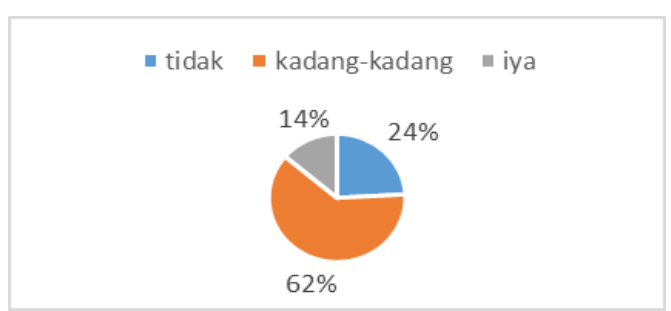

Gambar 8. Persepsi guru tentang penggunaan alat musik untuk mengiringi lagu

\section{Apakah guru menggubah syair lagu?}

Data penelitian menunjukkan bahwa $45 \%$ guru menggubah lagu dengan alasan syair yang diajarkan anak dapat disesuaikan dengan kondisi dan lingkungan. $45 \%$ Guru lainnya kadang-kadang menggubah lagu. $7 \%$ guru tidak menggubah lagu dan 3\% guru belum menggubah lagu. Gambar lebih jelas dapat dilihat pada gambar 9 .

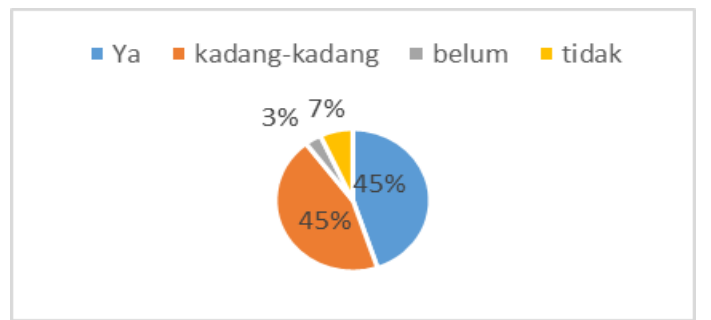

Gambar 9. Persepsi guru tentang menggubah syair lagu

\section{Bagaimana cara guru mengenalkan lagu baru pada anak-anak?}

Terdapat 38\% guru mengenalkan lagu baru dengan memberi contoh menyanyikan lagu terlebih dahulu. 34\% guru membacakan syair per kalimat kemudian ditirukan anak. $14 \%$ guru menggunakan cara mengenalkan lagu baru dengan mengulang-ulang lagu. $7 \%$ guru menjelaskan tema yang sesuai dengan lagu dan $7 \%$ lainnya guru menyesuaikan dengan lagu. 
Nur Hayati, Arumi Savitri Fatimaningrum, Rina Wulandari, Muthmainnah

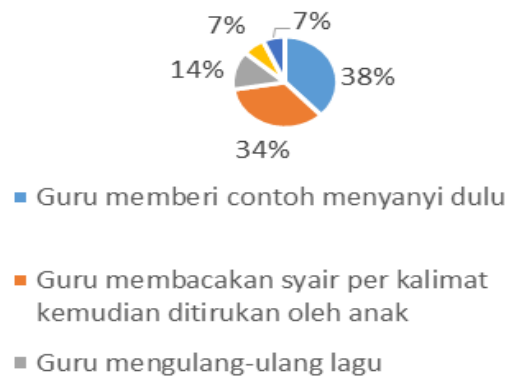

Gambar 10. Persepsi guru tentang cara mengenalkan lagu baru

\section{Darimana Guru mendapatkan ide atau referensi lagu baru?}

Data menunjukkan bahwa sebagian besar (14) guru mendapat ide atau referensi lagu baru dari pelatihan atau workshop. 10 Guru mendapatkan referensi dari browsing di internet, 5 guru mendapatkan ide dari buku atau majalah, 4 guru mendapatkan ide dari teman sejawat. Sebagian kecil lainnya guru mendapatkan ide atau referensi lagu baru dari media sosial dan acara di gugus. Penjelasan lebih lengkap dapat dilihat pada gambar 11.

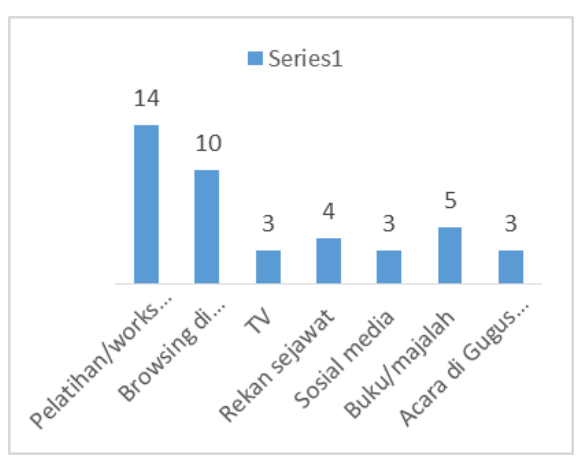

Gambar 11. Persepsi guru darimana mendapatkan ide atau referensi lagu baru

\section{Bagaimana guru mendapatkan ide atau referensi lagu baru?}

Data penelitian menunjukaan sebagian besar (7) guru mendapatkan ide atau referensi lagu baru dengan browsing di internet. 4 guru mendapatkan ide dari rekan sejawat, dan 4 guru lainnya mendapatkan dengan menonton televisi. 3 guru mendapatkan ide dengan mengikuti diklat atau workshop, 3 guru mendapat ide dengan mendengarkan radio dan 3 guru lainnya mendengarkan lagu anak-anak. 2 Guru yang lain mendapatkan ide melalui merenung, 2 guru dari pengalaman pribadi, 2 guru mendapatkan ide dan referensi dengan studi banding dan mendapatkan saran orang tua. Data lengkapnya dapat dilihat pada gambar 12 .

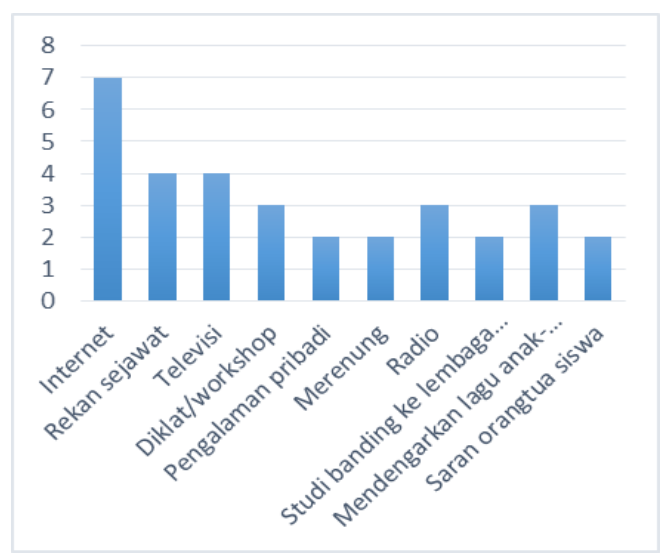

Gambar 12. Persepsi bagaimana Guru mendapatkan ide atau referensi lagu baru? 
Nur Hayati, Arumi Savitri Fatimaningrum, Rina Wulandari, Muthmainnah

\section{Sudah sesuaikah lagu yang diberikan guru dengan tinggi rendah suara anak?}

Hasil penelitian menunjukkan bahwa sebagian besar (62\%) guru sudah menyesuaikan lagu yang diberikan dengan tinggi rendah suara pada anak. $21 \%$ Guru menyatakan belum menyesuaikan dengan tinggi rendah suara anak, $10 \%$ guru kadang-kadang menyesuaikan tinggi rendah suara anak. $4 \%$ Guru menyatakan tidak menyesuaikan dan 3\% guru belum menyesuaikan lagu dengan tinggi rendah suara anak. Data lengkapnya dapat dilihat pada gambar 13.

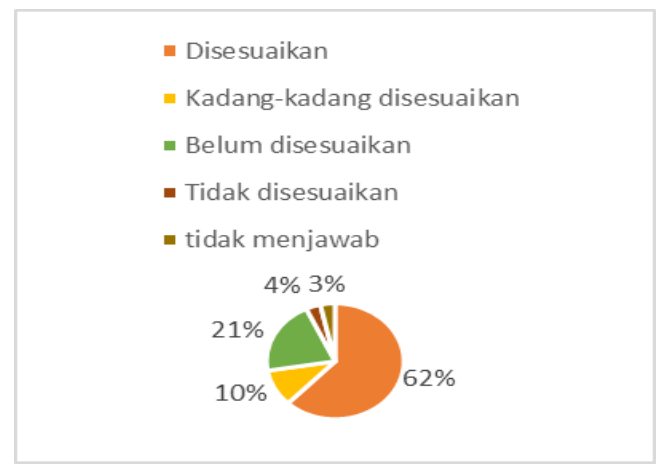

Gambar 13. Persepsi guru menyesuaikan lagu dengan tinggi rendah suara anak

\section{Pembahasan}

Berdasarkan hasil penelitian di lapangan, guru mempunyai persepsi bahwa kegiatan menyanyi dapat menstimulasi aspek perkembangan anak. Apa yang dirasakan guru mengenai kegiatan menyanyi dan apa yang dilakukan guru ketika mempersiapkan lagu yang akan disampaikan dalam pembelajaran. Hampir seluruh bentuk nyanyian dari yang tradisional sampai dengan yang trend dapat dimanfaatkan oleh guru dalam pembelajaran (Ridwan \& Awaluddin, A.F., 2019). Guru dapat mengenalkan berbagai jenis lagu pada anak usia dini untuk memperkaya pengetahuan dan perilaku anak sehari-hari.

\section{Apa yang dirasakan guru dalam kegiatan menyanyi}

Hasil penelitian menunjukkan bahwa $86 \%$ guru meminati menyanyi dan merasa senang saat menyanyi. 97\% Guru mempunyai persepsi bahwa kegiatan menyanyi juga dapat mempengaruhi aspek perkembangan lain selain aspek seni. Sesuai dengan tujuan pembelajaran dalam kurikulum 2013 bahwa setiap kegiatan pembelajaran dapat mengembangkan 2 atau 3 kompetensi dasar. Dengan demikian pesan moral dari syair lagu dapat tersampaikan pada anak dan dapat mengubah perilaku anak.

Sesuai dengan pendapat Irwanto (2002: 71) bahwa setelah individu melakukan interaksi dengan objek-objek yang dipersepsikan maka akan menghasilkan persepsi yang positif dan negatif. Kegiatan menyanyi secara umum dapat meningkatkan sikap positif anak-anak baik anak laki-laki maupun anak perempuan, dari berbagai usia dan status sosial yang berbeda (Barrett, M.S. et al., 2018).

\section{Apa yang dilakukan dalam kegiatan menyanyi?}

Hasil penelitian menunjukkan bahwa yang dilakukan guru dalam kegiatan menyanyi antara lain menyiapkan lagu sesuai dengan tema pembelajaran. Guru mencantumkan kegiatan menyanyi dalam RPPH. Guru anak usia dini perlu merencanakan kegiatan menyanyi dalam RPPH dan mengemas kegiatan secara menarik agar anak didik setiap hari bergairah dan termotivasi untuk melakukan kegiatan pembelajaran dan senang belajar sambil bermain di sekolah (Susilawati, 2014). Hasil penelitian menunjukkan $62 \%$ guru kadang-kadang menggunakan alat musik untuk mengiringi anak menyanyi. Hal tersebut disampaikan guru karena tidak semua sekolah memiliki fasilitas alat musik. Sesuai dengan pendapat Wulandari (2011) bahwa irama yang dikenalkan pada anak usia dini adalah irama yang sederhana. Bagi guru yang tidak memiliki kemampuan menggunakan alat musik dapat menggunakan barang bekas atau anggota tubuh unruk mengiringi anak menyanyi. Hasil penelitian selanjutnya menunjukkan bahwa $45 \%$ guru menggubah lagu untuk disesuaikan dengan tema pembelajaran. Guru juga mempunyai berbagai cara untuk mengenalkan lagu baru antara lain dengan memberikan contoh terlebih dahulu dan mengulang-ulang syair lagu agar mudah dihafalkan anak. Wulandari (2011) juga berpendapat bahwa mengenalkan lagu pada anak usia dini perlu diulang-ulang agar anak mengerti irama lagu dan dapat disesuaikan dengan tinggi rendah suara anak. 
Nur Hayati, Arumi Savitri Fatimaningrum, Rina Wulandari, Muthmainnah

Guru hendaknya dapat memilih atau menyeleksi atau menciptakan lagu yang bisa digunakan baik untuk menyanyi bersama maupun dalam bernyanyi sambil melakukan kegiatan (Muhaiban, 2002:5). Berdasarkan hasil penelitian ditemukan bahwa guru mendapatkan ide atau referensi lagu baru dari pelatihan, dari teman sejawat, dari media audio visual dan dari media sosial. Berbagai media tersebut sangat efektif menambah pengetahuan guru tentang lagu khususnya dalam rangkan menyesuaikan lagu dengan tema pembelajaran.

\section{SIMPULAN}

Kegiatan menyanyi hampir dilakukan setiap hari, baik di saat kegiatan pembukaan, inti, maupun penutup dalam pembelajaran anak usia dini agar anak tidak bosan belajar. Namun sebagian guru belum mengajak anak menyanyi sesuai dengan tema pembelajaran. Menyanyi dilakukan anak baik secara individu maupun kelompok dan kegiatan menyanyi dapat dijadikan sebagai dasar untuk menilai proses belajar anak ketika anak mampu menunjukkan adanya perubahan perilaku.

Persepsi guru terhadap kegiatan menyanyi dikategorikan dengan pengetahuan yang dimiliki guru tentang menyanyi yang selama ini sudah dilakukan. Persepsi guru terhadap apa yang dirasakan saat melakukan kegiatan menyanyi sebagai acuan dalam memaknai lagu sesuai dengan tema pembelajaran. Persepsi guru tentang apa saja yang dilakukan dalam kegiatan menyanyi sebagai landasan bahwa menyanyi bukan sekedar intermezzo namun sebagai aktivitas seni yang harus jelas referensinya dan disesuaikan dengan tinggi rendah suara anak.

\section{UCAPAN TERIMA KASIH}

Bagian ini berisi ucapan terima kasih kepada sponsor atau pendonor dana, atau kepada pihak-pihak yang secara penting berperan dalam pelaksanaan penelitian.

\section{DAFTAR PUSTAKA}

Ali, M. \& Asrori, M. (2009). Psikologi remaja: pengembangan peserta didik. Edisi 6. Jakarta: PT Bumi Aksara.

Barrett, M.S. et al. (2018). Evaluating the impact of a generalist teacher-led music program on early childhood school children's singing skills and attitudes to music. Sempre, journals.sagepub.com/home/pom, DOI: 10.1177/0305735618790355

Christianti, M., Hayati, N., Fatimaningrum, A.S. (2017), Penerapan LEA (Language Experience Approach) melalui Cerita Budaya Lokal untuk Mendukung Membaca Awal pada anak di TK, Laporan penelitian Fakultas Ilmu Pendidikan Universitas Negeri Yogyakarta, Yogyakarta

Hayati, N., Muthmainnah, Rahmawati, R. (2015). Development of conomy Token Model In Early Childhood Learning", diterbitkan dalam Proceeding 2nd International Conference on Current Issues in Education, 25-26 Agustus 2015, ISSN:2460-7185, Available at: http://pps.uny.ac.id/sites/pps.uny.ac.id/files/Proceding-final-cd-LV.pdf

Irwanto. (2002). Psikologi umum. Jakarta: PT Prenhallindo.

Menteri Pendidikan dan Kebudayaan Republik Indonesia. (2014). Peraturan menteri pendidikan dan kebudayaan republik indonesia nomor 137 tahun 2014 tentang standar nasional pendidikan anak usia dini, Jakarta, Available at: http://disdik.banjarbarukota.go.id/produk_hukum/Permendikbud\%20Standar\%20 Nasional\%20PAUD.pdf

Muhaiban. (2002). Strategi Pembelajaran Al-Arabiyah Lil-Athfal. Malang: Makalah disajikan Dalam Pelatihan Pembelajaran Bahasa Arab Untuk Anak di Fakultas Sastra Universitas Negeri Malang.

Ridwan \& Awaluddin, A.F. (2019). Penerapan metode bernyanyi dalam meningkatkan penguasaan mufradat dalam pembelajaran bahasa arab di raodhatul athfal. Didaktika jurnal kependidikan, volume 13, No 1 Juni, P-ISSN 19780214; E-ISSN2657-196X

Slameto. (2010). Belajar dan faktor-faktor yang mempengaruhinya. Jakarta: PT Rineka Cipta.

Solso, R.L., Maclin, O.H., \& Maclin, K.M. (2007). Psikologi kognitif. edisi kedelapan. (Alih bahasa: Rahardanto, M. \& Bartuadji, K.). Jakarta: Erlangga.

Susilawati. (2014). Penerapan metoda bernyanyi dalam meningkatkan kecerdasan berbahasa pada 
Jurnal Pendidikan Anak, 8 (2), 2019

Nur Hayati, Arumi Savitri Fatimaningrum, Rina Wulandari, Muthmainnah

pendidikan anak usia dini (studi deskriptif tentang penerapan metoda bernyanyi di PAUD Al Azhar Syfa Budi Parahyangan). Jurnal Empowerment Volume 4, Nomor 2 September, ISSN No. $2252-4738$

Wulandari, R. (2011). Pengembangan lagu untuk anak usia dini 4-6 tahun, Dinamika Pendidikan Vol.18 No.2, Fakultas Ilmu Pendidikan Universitas Negeri Yogyakarta, Yogyakarta, Available at:https://journal.uny.ac.id/index.php/dinamika-pendidikan/article/view/4080/0 